УДК 94 : (477.83/.86) «1939/1941»

DOI https://doi.org/10.31470/2518-7732-2019-1(15)-21-31

\section{Старка Володимир,}

кандидат історичних наук, доцент, доцент кафедри історії України, археології та спеціальних галузей історичних наук, starka1980@ukr.net http://orcid.org/0000-0002-0213-9298 «Державний вищий навчальний заклад Тернопільський національний педагогічний університет імені Володимира Гнатюка», м. Тернопіль, вул. М. Кривоноса, 2, Тернопільська область, Україна, 46027

\author{
Starka Volodymyr, \\ $\mathrm{Ph}$ D (History), Associate Professor \\ of Ukraine's History Department \\ of History of Ukraine, Arheology \\ and special branches of \\ historical science, \\ starka1980@ukr.net \\ http://orcid.org/0000-0002-0213-9298 \\ Ternopil Volodymyr Hnatiuk \\ National pedagogical University, \\ M. Kryvonos, 2, Ternopil, \\ Ternopil region, Ukraine, \\ 46027
}

\title{
Культурно-масове життя сільського населення Західної України в умовах суспільних трансформацій 1939-1941 років
}

Сучасне культурно-масове життя західноукраӥнського селянства є унікальним симбіозом звичаїв, щчо своӥм корінням сягають часів Австро-Угорщини, із вкрапленнями польської міщанської та радянської пролетарської культур. Дослідження явищ і процесів, щзо істотно впливають на культурне життя сільських мешканиів, як однієї із найконсервативніших частин суспільного організму може дати сучасникам розуміння, в якому спектрі буде розвиватися сучасне культурне життя села. В изьому вбачаємо актуальність нашого дослідження.

Використання попередніх напрацювань українських істориків, із залученням нового джерельнодокументального комплексу, дозволило по-новому проаналізувати культурно-масове життя селянства досліджуваного періоду.

Методологічні підходи написання дослідження трунтуються на аналізі різноманітних моделей культурномасового життя селянства, у конкретно-історичних обставинах, в умовах радянського тоталітарного режиму. Матеріал публікації структурований за проблемно-хронологічним принципом. Теоретичні узагальнення здійснено з використанням методів індукиії та дедукиії.

У процесі аналізу культурного життя західноукраӥнського села встановлено, щзо запропоновані радянської владою перетворення в культурній сфері носили характер національний за формою та соиіалістичний за змістом. Увесь комплекс культурних заходів радянської влади мав долучити західноукрайнських селян до надбань радянської культури та виробити в них відчуття радянської людини.

Зауважимо, щзо характерною рисою регіону є тотальна набожність та стійке дотримання релігійнообрядового календаря у повсякденних практиках населення. Зазвичай, західноукраӥнське селянство сприймає будь-які новачії з точки зору порушують чи не порушують вони усталеного способу життя. Відзначимо, що більшість громадян регіону, на початку з цікавістю поставилися до запроваджуваних новацій і навіть стала приймати активну участь у їх поширенні. Потрібно наголосити, щзо доволі впливова у Західній Україні греко-католицька иерква, поставилася до запроваджуваних культурних новачій із певними засторогами $і$ закликала своӥх прихожан не долучатися до заходів, щзо суперечать усталеній моральній традиції. Власне, здійснювана новою владою політика ревізї фонді сільських бібліотек, надмірна політизащія культурного дозвілля, поруч із активною антирелігійною кампанією, привели до різкого неприйняття місцевими культурних новачій нової влади. Відвертий «культурний» конфлікт місиевих із радянською владою зупинив початок німецько-радянської війни у червні 1941 року.

Ключові слова: Західна Україна, селянство, культурно-масове життя, суспільно-політичні трансформації.

\section{Cultural and Mass Life of the Rural Population of Western Ukraine under the Conditions of Social Transformations of 1939-1941}

The modern cultural and mass life of the Western Ukrainian peasantry is a unique symbiosis of customs that dates back to the times of Austro-Hungary, with the split of Polish bourgeois and Soviet proletarian cultures. The study of phenomena and processes that have a significant impact on the cultural life of rural residents as one of the most conservative parts of a social organism can give contemporaries an understanding in which spectrum the modern cultural life of villages will develop. Thus our study is relevant nowadays.

Using the previous works of Ukrainian historians along with a new source-documentary complex enabled the analysis of the cultural and mass life of the peasantry of the researching period.

Methodological approaches to writing this research are based on analysis of various models of the cultural and mass life of the peasantry in particular historical circumstances under the conditions of the Soviet totalitarian regime. The material of the publication is structured according to the problem-chronological principle. Theoretical generalizations are made using the methods of induction and deduction. 
In the process of analyzing the cultural life of the Western Ukrainian village it was established that the Soviet authorities proposed the transformation of it into national on the form but socialist in content. The whole complex of cultural measures of Soviet power was aimed at involving Western Ukrainian peasants into the achievements of the Soviet culture and developing a sense of a Soviet man in them.

It's worth mentioning that the characteristic feature of the region is total religiosity and consistent observance of religious ceremonial calendar in everyday practices of the population. The Western Ukrainian peasantry ususally perceives any innovations from the perspective of violating or not the established lifestyle. It should be admitted that the majority of citizens in the region, initially with interest responded to the innovations introduced and even began to take an active part participating in their distribution. It is necessary to emphasize that quite influential in the West Ukraine, the Greek Catholic Church, treated the cultural introduced innovations with certain precautions and urged their parishioners not to practice what contradicts the established moral tradition. Actually, the carried out new government's policy of auditing the fund of rural libraries, excessive politicization of cultural leisure, along with an active anti-religious campaign led to the abhorrence of local cultural innovations of the new government. The outright "cultural" conflict between the local and the Soviet authorities was stopped by the German-Soviet War in June 1941.

Key words: Western Ukraine, peasantry, cultural and mass life, socio-political transformations.

Поточний момент розвитку української державності, коли відбувається перехід від тоталітарної моделі управління суспільством до демократичної, надає кожному громадянину рівні та вільні можливості праці та відпочинку. Сучасна індустрія розваг сягнула неймовірних висот. Соціологи та політологи пропонують наукові розвідки на тему, як напрацювання цієї сфери суспільного життя можуть моделювати поведінку людей у майбутньому. У цьому сенсі цікавим видається дослідження культурного повсякдення людей за умов змін політичних режимів. Адже у ці переломні моменти буття, найчастіше відбувається трансформація найусталеніших способів культурного проведення дозвілля.

Пропонуємо розглянути питання зміни усталеного способу життя в умовах становлення радянським тоталітарним режимом на прикладі культурного життя західноукраїнського селянства. Оскільки сучасне культурно-масове життя західноукраїнського селянства $\epsilon$ унікальним симбіозом звичаїв, що своїм корінням сягають часів Австро-Угорщини, із вкрапленнями польської міщанської та радянської пролетарської культур. Потрібно зазначити, що у 1930-х роках, сільське населення Східної Галичини на теренах Східної Свропи залишалося чи не найконсервативнішою спільнотою, як в сенсі господарського, так і культурного життя. Для тодішньої польської влади головне завдання полягало в утриманні регіону в певному політичному спокої, а що роблять люди у вільний від роботи час офіційній владі було байдуже.

Події вересня 1939 року в житті західноукраїнських аграріїв змінили не лише громадянство, але і започаткували глибинні перетворення у їх культурному житті.

Питання змін у культурі та побуті населення Західної України доволі широко висвітлене у працях радянських істориків. Основні тези цього напряму викладено у брошурах заступника голови РНК (РМ) УРСР Л. Корнійця «Соціалістичні перетворення в західних областях Української РСР» [22], та секретаря Львівського обкому КП(б)У І. Грушецького «Соціалістичні перетворення на Львівщині» [16]. Із робіт фахових істориків звернемо увагу на дослідження В. Келембетової та О. Кувеньова [17; 24]. Як підсумок напрацювань означеної тематики радянськими істориками, у 1989 р. побачила світ колективна монографія «Соціалістичні перетворення в культурі та побуті західноукраїнських областей України» [32]. Варто наголосити, що радянські наукові дослідження хоч і містять доволі добротний фактологічний матеріал, водночас мають лише одне ідеологічне спрямування - висвітлення переваг соціалістичної культури над буржуазною. Реакцію місцевих жителів на процеси радянізації краю опубліковано на сторінках збірки спогадів упорядкованої на заході М. Рудницькою [31]. Відкриття архівних матеріалів дозволило сучасним українським дослідникам по-новому поглянути на процеси у культурному житті зазначеного періоду. Зокрема у 1995 році львівські дослідники підготували до друку тритомний збірник документів під загальною назвою «Культурне життя в Україні» [26]. Серед сучасних дослідників, виокремимо праці М. Литвина, Ю. Киричука, В. Барана, К. Кондратюка $[1 ; 18 ; 21 ; 28]$. Разом із тим, констатуємо, що попри значну кількість наукових публікацій, питання повсякденного культурно-масового життя сільських мешканців не стало предметом наукових зацікавлень.

Мета дослідження проаналізувати політику радянської влади у культурно-масовій сфері та відобразити іï вплив на трансформацію повсякденного життя західноукраїнських селян.

Завдання публікації обумовлені аналізом різноманітних джерел, характеристикою механізму трансформацій в культурній сфері на повсякденне життя сільського населення Західної України. 
Очевидно, що формат публікації не дозволить розкрити усіх особливостей процесу культурної радянізації західноукраїнського села, тому зупинимося на ключових аспектах цього процесу.

За «часів Польщі», культурно-масове життя сільського населення було доволі розміреним та одноманітним. У будні дні селяни працювали на своїх земельних наділах, чи залучалися до виконання громадських робіт. У неділю, традиційно всі родини відвідували церкву. Після служби сільські господарі на якийсь час затримувалися на майдані біля церкви, щоб обговорити суспільно-політичну ситуацію в країні та останні події з життя села. У вечері в сільському клубі могли організувати зусиллями аматорських гуртків концерт чи виставу. Під час Різдвяних свят селяни ходили з колядою, а у час Великодня центром сільського дозвілля ставало церковне подвір'я, де молодь водила гаївки та мала різні забави. Особливою популярністю користувалася гра у «ремінця» (у прикарпатському регіоні «шикало») [4, арк. 7].

Часто по неділях вчителі «Рідної Школи» читали у сільських клубах лекції з господарської чи суспільно-історичної тематики [20, с. 111].

Події вересня 1939 року внесли у повсякденне життя західноукраїнського селянства чимало новацій. Перебуваючи у стані певної ейфорії, селяни інтуїтивно відчували, що несподіваний крах ненависної їм Польської держави, це лише початок змін, що чекали їх попереду.

Насамперед насторожував людей зовнішній вигляд носіїв «високої радянської культури». Новоприбулі «брати зі Сходу» суттєво відрізнялися своєю поведінкою та манерами, скромним одягом. Радянські офіцери на тлі польських чи німецьких колег, в очах селян, виглядали звичайними «шміраками». Образ брудних і виснажених червоноармійців красномовно доповнювали гвинтівки, що висіли за їх спинами на простих мотузках і лексикон, рясно наповнений перлами ненормативної лексики, яких раніше ніхто не чув у селах [23, с. 137].

Із перших днів радянський режим розпочав активно впроваджувати у життя нову модель культурно-масового життя, суть якої ілюструє теза з листа на ім'я Й. Сталіна учасників І обласної партійної конференції КП(б)У Тернопільської області, що відбулася 23 квітня 1940 р. серед іншого у документі наголошено: «...3 кожним днем розвивається нечуваний розквіт культури, національний за формою, соціалістичний за змістом» [10, арк. 18].

«Визвольний похід» Червоної армії відбувався під гучним музичним супроводом. Музика і пісні звучали з гучномовців, які розташовувалися на спеціальних військових автомобілях, які зазвичай приїзджали у центр села перед зборами чи мітингами. Останні відбувалися в селах чи не щодня. Перші тижні становлення радянської влади у західноукраїнському селі можна назвати суцільними «оглядами народної творчості». 3 території УРСР направлено для роботи 3 військовими частинами та місцевим населенням театральні, музичні, хорові, естрадні колективи. На залізничні станції прибували агітаційні потяги та пересувні виставки радянського мистецтва [27, с. 95].

Водночас на новоприєднані землі радянськими відділами агітації та пропаганди завезено сотні тисяч примірників агітаційних матеріалів. Серед них: численні варіанти листівок, брошур iз описами «щасливого радянського життя», різножанрові плакати, портрети керівників партії та держави. Зокрема, лише через систему Львівської облконтори книгокульторгу, за час від жовтня 1939 до березня 1940 р. поширено серед населення: 20100 примірників Конституції УРСР українською мовою вартістю 4020 крб., Конституції СРСР (українською мовою) 22490 екземплярів вартістю 3373 крб., та 3960 примірників Конституції СРСР вартістю 792 крб. польською мовою. Крім того, відпущено 68124 примірники Положення про вибори вартістю 6812.50 крб. Також відпущено 2994 портрети Й. Сталіна вартістю 1946 крб., та 2995 портретів В. Молотова вартістю 1946 крб. [5, арк. 113].

Особливу увагу нова влада приділяла поширенню серед селян радянської періодичної преси. Наприклад лише в Тернопільській області на початку 1940 р. виходила одна обласна та 12 районних газет [11, арк. 30].

Варто зазначити, що згадані видання своїм змістом мало чим відрізнялися одне від одного. Зазвичай на перших шпальтах передруковували передові статті московських чи київських центральних газет, і лише на останніх шпальтах друкували регіональні відомості. Структура місцевих засобів масової інформації визначалася їх основним завданням - переконати місцевих мешканців у перевагах соціалістичного способу життя. «Компетентні органи» пильно слідкували, щоб у пресі не було надруковано ідеологічно не виваженої інформації. Наприклад головний редактор Кременецької районної газети «Сталінським шляхом» у 1940 р. отримав догану за визначення завдань радянської преси, яке полягало в наступному: Радянська преса це 
приводний ремінь від партії і уряду до мас і від мас до партії і уряду. Маси через пресу формують громадську думку і таким чином впливають на рішення партії і уряду в місцевому і державному масштабі [12, арк. 76].

Щоб газета була доступною жителям, у центрі кожного села встановлювалися спеціальні вітрини, де розміщували примірники газет. Щоправда, іноді газети змінювали лише перед виборами, чи приїздом високого керівництва з району чи області.

Особливе місце у системі виховання культури «нової радянської людини» займав сільський клуб. Власне за часів Польської держави більшість приміщень сільських клубів споруджувалися за пожертви місцевих мешканців, і будувалися їх зусиллями. При сільських клубах поруч із аматорськими хоровими та театральними гуртками, діяли просвітницькі філії товариств «Просвіта», «Рідна школа» тощо. Зазвичай при згаданих товариствах діяли бібліотеки, де бажаючі могли отримати літературу історико-суспільного чи соціально-економічного характеру.

Радянська влада швидко прибрала до своїх рук керівництво над цими центрами культурномасового життя села. Заборонивши діяльність означених товариств при сільських клубах відкрито хати-читальні, «червоні кутки». Зокрема, лише у листопаді 1939 р. у селах Золочівського району Львівської області відкрито 25 червоних кутків [6, арк. 2 зв.].

Як згодом пригадував священик із с. Дуліби Новострілківського району Львівської області: «... на місці читальні постав клуб, бібліотеку вивезли, натомість щонеділі грала музика [35, арк. 49 г].

Сільський клуб за задумом радянських пропагандистів мав стати центром «культурномасової роботи» [13, арк. 80]. Селяни мали змогу тут читати газети, журнали, відвідувати лекторії. Щоправда, нова влада вилучила із старих бібліотек «націоналістичну літературу»: художні твори, книги з історії України, літературу релігійної тематики. Натомість поступово фонди сільських бібліотек поповнювала класика радянської літератури. Як зазначалося у звіті відділу пропаганди, Тернопільського обкому на початку 1940 р.: «в ряді сіл клуби та хати читальні засмічені ворожими елементами, досі не завершене очищення бібліотек від контрреволюційної літератури, та не наповнено їх сховища радянськими виданнями» [13, арк. 80].

Після таких чисток, у бібліотеках залишалося «в середньому 100-150 книжок» [9, арк. 15].

Одночасно із ревізією книжкових фондів, нова влада провела і кадрові ротації. «Політично ненадійний елемент» замінили на представників «соціально близьких» класів - сільської бідноти, що породжувало і комічні ситуації так, у с. Турази Жидачівського району Львівської області завклубом назначили колишнього сільського злодія В. Чехановича [33, арк. 16].

Із метою підвищення фахового рівня керівників сільських клубів, організовували відповідні курси підготовки та екскурсії у сусідні області УРСР [24, с. 65].

Значні кошти радянська влада виділяла на розвиток кінофікації у західноукраїнському селі. Перше знайомство із радянським кінематографом у селян відбулося за посередництва політуправління Червоної Армії. Зокрема в с. Куряни Кременецького району Тернопільської області відділом пропаганди військової частини продемонстровано кілька кінофільмів [24, с. 63]. Згодом у селах мали запрацювати пересувні кіноустановки. Репертуар не вражав асортиментом. Зокрема, демонстрували класику радянської пропаганди кінофільми: «Щорс», «Ленін в жовтні», «Виборгська сторона», «Багата наречена», «1918 рік», «Чапаєв» [6, арк. 2]. Щоправда, їх була доволі обмежена кількість. Так, у Львівській області станом на 1 червня 1940 р. працювало лише 2 пересувні кіноустановки [7, арк. 89]. У сусідній Тернопільській області працювало 13 кінопересувок, «які упродовж грудня 1939 - січня 1940 р. обслужили 100084 селян» [11, арк. 54]. Хоча як зазначалося у звіті відділу пропаганди Тернопільського обкому: «в окремих районах не відбувається популяризація радянських кінофільмів» [13, арк. 80].

Потрібно зазначити, що якоїсь чіткої системи кінообслуговування сільського населення у досліджуваний період радянська влада так і напрацювала. Кінопересувки працювали не систематично, часто виходили з ладу. На роботі установок позначалася і відсутність централізованого електропостачання у селах. Дизель-генератори, якими були обладнані мобільні кіноустановки часто також не працювали. Ситуацію із демонстрацією кінофільмів у селах яскраво ілюструє звіт управління кінофікації Львівської області, у котрому серед іншого зазначено: «перед війною в селах не працювала жодна кіноустановка» [7, арк. 118].

Особливу увагу в культурно-масовій роботі сільських клубів приділяли лекційній пропаганді. В сільських клубах працювала ціла армія лекторів. Держава виділяла значні кошти на їх роботу. Львівське лекційне бюро розробило на 1940-1941 роки методичні рекомендації 
стосовно тематики, порядку читання та оплати лекцій. Відповідно до документу, у тематиці домінували доповіді антирелігійного та господарського спрямування. Селянам розповідали про «Походження і класову сутність Різдва», «Міф про Христа», «Виявлення чудес релігії» тощо. Зрозуміло, що подібні лекції селяни намагалися не відвідувати, хіба що під примусом. Натомість лекції на яких навчали селян правильно поводитися із домашніми тваринами, як займатися бджільництвом, як боротися із шкідниками користувалися популярністю. За свою роботу лектори отримували доволі пристойну платню, так лекція професора коштувала 110 крб., доцента 88 крб., артиста-читця залежно від категорії від 66 до 99 крб. Окрім того, якщо лекція не відбулася з вини замовника, лектору виплачували 50 \% вартості лекції. Лектор чекав збору слухачів 30 хв., якщо ніхто не приходив, то він повертався до дому. Додатково було обумовлено, що у випадку віддаленості залу для читання лекцій на відстань більше ніж 1 км від залізничної станції, замовник має надіслати за лектором підводу чи авто. Якщо це не було надано, лектор мав право повернутися, проте замовник повинен був здійснити 100 \% оплату лекції і проїзду [29, с. 46].

Навіть за таких умов, лектори не завжди належно виконували свою роботу. Так, в Кременецькому районі Тернопільської області у звіті відділу пропаганди за 1940 р. зазначалося: «на дуже низькому ідейно-політичному рівні читалися пропагандистські лекції з історії СРСР» [12, арк. 91]. Керівництво Лановецького РК Тернопільської області отримало догану від керівництва області, за те, «що в неділю в селах, коли селяни вільні від роботи, ніхто не проводить політико-агітаційної роботи. А якщо заходи і відбуваються, то доповідачі не готові відповідати на запитання селян» [15, арк. 108].

Щоб уникати подібних ситуацій, управління агітації і пропаганди місцевих обкомів КП(б)У рекомендували залучати до роботи в клубах сільську інтелігенцію, котра мала безкоштовно читати наукові і масово-популярні лекції [14, с. 109].

Окрім читання лекцій на актуальні суспільно-політичні теми, радянська влада підтримувала діяльність самодіяльних творчих гуртків. Наприклад, у Станіславській області лише у 1939 р. у сільських клубах організовано 1754 гуртки народної самодіяльності, до роботи яких залучено 22774 осіб. Правда, у звіті управління агітації та пропаганди Станіславського обкому КП(б)У зазначалося: «ніякого обліку їх роботи не ведеться. В одному із сіл під час перевірки з'ясувалося, що гурток працює в селянському будинку, де навіть немає печі» [2, арк. 18].

У сусідній Тернопільській області станом на 1 листопада 1940 р. при 1223 сільських клубах і хатах-читальнях - 1938 гуртків художньої самодіяльності.

Нові віяння в сільській культурі трансформували репертуар хорових і драматичних гуртків. Замість української класики, як зазначено у звіті управління культури Львівського обкому КП(б)У «всі гуртки вчать гімн Радянського Союзу, «Пісню про Сталіна», поему П. Тичини «Я стверджуюсь», п’єсу Мокрієва «Журавлі летять» [9, арк. 9, 14]. Можна припустити що подібна ситуація стала реакцію на низку прикрих інцидентів, що мали місце під час чергових святкувань річниці Жовтневої Революції. Зокрема, залучений до виступу під час урочистостей у листопаді 1940 р. церковний хор с. Августівка Зборівського району Тернопільської області замість «Інтернаціоналу» виконав національний гімн «Ще не вмерла Україна». За словами очевидців: «Приявні на святі представники влади щиро оплескували український гімн» [34, арк. 26].

Нова влада намагалася у сільське дозвілля впровадити практику святкування радянських свят. Так, в жовтні 1939 р. зусиллями партійних і комсомольських організацій в селах Станіславської області проведено урочисті збори присвячені 22 річниці Жовтневої революції [2, арк. 6].

Окрім суто політичних: Дня Жовтневої революції чи Червоної армії, активно пропагувався радянський варіант святкування Нового року й особливою до цих святкувань залучали учнів молодших класів. Як альтернативу Різдвяним, а особливо Великоднім святам, пропонували проведення в селах різного роду спортивно-масових заходів, фестивалів художньої самодіяльності тощо.

Потрібно наголосити, що не завжди ці дійства були безкоштовними. Відповідно до радянського фіскального законодавства з культурно-масових заходів, комерційних спортивних змагань, місцева влада збирала податки за встановленими розмірами. Так, із вистав, концертів, сплачувалося 10 \% вартості квитка, громадських ігор - $15 \%$, естрадних виступів, каруселей, різного роду атракціонів - $20 \%$, танцювальних вечорів - $60 \%$ [3, арк. 65].

Місцеве населення зазвичай не приймало активної участі у радянських забавах. Водночас частина сільського люмпену, спільно із колись «добропорядними громадянами» долучалося до 
нових святкувань. Так, за спогадами пароха с. Поляні Щирецького району Львівської області колишній дяк В. Дума: «під час свят і неділь запивався горілкою, як більша часть парафіян, 1 травня 1941 р. ніс на переді походу образ Сталіна» [36, арк. 30].

Як зазначав історик М. Литвин: «дезорієнтовані пропагандою селяни, на певний час не мали чіткого розуміння ситуації і сприймали бажане за дійсне. Частину українців вдавалося втягнути у політичні спектаклі, доручаючи їм виступати на численних мітингах і зборах, підписувати звернення і петиції [28, с. 107-108].

Загалом, культурно-масове життя сільського населення Західної України «за перших совітів» замість «організації культурних розваг (читання лекцій, доповідей, проведення бесід, показу художньої самодіяльності)», в більшості клубів звелося до організації забав. Радянські документи відзначають в ряді сільських клубів кричущу антисанітарію, приміщення як правило не відремонтовані [14, арк. 108]. Львівський сільський Районний Комітет КП(б)У констатував, що навесні 1941 р.: «як правило вечорами в селі не працює ніякий культурний заклад, в селах не буває пересувна кіноустановка, радіо теж немає» [8, арк. 49].

Греко-католицька церква, як найбільш впливова моральна інституція у західноукраїнському селі, у перші місяці радянської влади до запроваджуваних більшовиками новацій поставилася хоч 3 певною засторогою, проте відкрито не закликала своїх прихильників до саботажу. Натомість, коли у 1940 р. нова влада перейшла до відвертої антирелігійної пропаганди, в тому числі використовуючи засоби масової культури, священики у недільних проповідях закликали парафіян у різний спосіб утримуватися від участі у пропонованих новою владою дійствах. Духовний лідер галичан А. Шептицький у листі до кардинала Є. Тірсена 26 грудня 1939 р. так описував ситуацію у селах: «здається все що виходить від властей, має на меті притіняти, руйнувати, нищити і завдавати болю, при тому всьому, неймовірне безладдя. Корумпування молоді, приваблювання їх всякими танцями, музикою, іграми та, врешті, пропагандою фанатичного атеїзму. Богу дякувати, сільське населення реагує з великою стійкістю, і ця реакція має дуже чистий, виключно релігійний характер» [30, с. 892-893].

Як бачимо із наведеної А. Шептицьким інформації, пропоновані радянською владою новації не знаходили широкої підтримки в середовищі селян. Більше того, західноукраїнські аграрії все частіше вороже реагували на дії влади. Назрівав конфлікт цінностей, що міг перерости у відкрите протистояння. Зупинив процес культурної інтеграції східногалицького села до радянського суспільства початок німецько-радянської війни у червні 1941 року.

Підсумовуючи вищевикладене зазначимо, що західноукраїнське селянство наприкінці 1939 року стояло на порозі суттєвих трансформацій культурно-духовного життя. Думки селян розділилися. Багаті та середньо заможні селянські верстви однозначно не підтримували запроваджувані радянською владою новації, та у різноманітний спосіб їх саботували. Натомість бідніші верстви, повіривши гаслам соціальної рівності, піддалися більшовицьким закликам. Сільська молодь, не маючи альтернативи дозвілля, відвідувала танці у клубах, в такий спосіб долучаючись до «радянської культури».

Погодимося $з$ думкою дослідника Р. Ковалюка, що заходи радянської влади у культурномасовій сфері носили двобічний характер. Із одного боку відбувався процес інтеграції західноукраїнського селянства до радянської суспільно-політичної дійсності засобами культури, проте разам із тим наддніпрянські українці пізнавали традиційну українську селянську культуру, звичаї якої відживали себе у них на Батьківщині [19, с. 14].

Можна констатувати, що радянській владі у досліджуваний період, незважаючи на зусилля пропагандистського апарату не вдалося досягнути значних змін усталеного способу життя місцевого селянства.

Загалом питання культурного взаємовпливу галичан і наддніпрянців у ході розбудови радянського суспільства, потребує окремого наукового осмислення.

\section{ДЖЕРЕЛА ТА ЛІТЕРАТУРА}

1. Баран В. К., Токарський В. В. «Зачистка»: політичні репресії в західних областях України у 1939-1941 рр. Львів : Інститут українознавства ім. І. Крип’якевича НАН України, 2014. $456 \mathrm{c}$.

2. Державний архів Івано-Франківської області. Ф. П. 1. Оп. 1. Спр. 5. Стенограмма совещания секретарей укомов партии, заведующих секторами агитации и пропаганды, первых секретарей укомов комсомола, комиссаров и начальников политотделов воинских частей о состоянии партийно-массовой работы в области. 21 грудня 1939 р. - 21 грудня 1939 р. 60 арк. 
3. Державний архів Івано-Франківської області. Ф. Р. 1. Оп. 1. Спр. 787. Постанови облвиконкому про порядок проведення місцевих податків і зборів в 1941 p. по Станіславській області. 28 вересня 1940 р. - 1 жовтня 1940 р. 65 арк.

4. Державний архів Івано-Франківської області. Ф. Р. 1576. Оп. 1. Спр. 144. Спогади Конищук М. О. 1892 р.н. с. Ковалівка Станіславської області. 1965. 35 арк.

5. Державний архів Львівської області. Ф. 221. Оп. 1. Спр. 79. Накази виконавчого комітету. Списки, довідки, схеми по виборах у ВР СРСР і УРСР. 1 січня 1940 р. - 8 березня 1940 р. 370 арк.

6. Державний архів Львівської області. Ф. 221. Оп. 1. Спр. 363. Інформація про стан господарського, культурного і політичного життя трудящих Золочівського повіту за 1939 р. станом на 15.11.1939 р. 1939 р. 3 арк.

7. Державний архів Львівської області. Ф. П 3. Оп. 1. Спр. 13. Доповідні, пояснювальні записки, відомості обласних радянських органів в обком КП(б)У про стан промисловості, сільського господарства, народної освіти, торгівлі, охорони здоров'я в області, відомості про висунення на керівні посади представників з місцевого населення. 2 січня 1940 р. 10 травня 1940 р. 140 арк.

8. Державний архів Львівської області. Ф. П 3. Оп. 1. Спр. 60. Інформації працівників обкому, міськкомів, райкомів партії про виконання постанов «Про недоліки в політичній роботі серед населення Західних областей УРСР». 9 травня 1944 р. - 20 червня 1944 р. 136 арк.

9. Державний архів Львівської області. Ф. П 3. Оп. 1. Спр. 75. Інформації, довідки обкому партії в ЦК КП(б)У про виконання постанов ЦК ВКП(б) від 27.09.1944 р. Про недоліки в політичній роботі серед населення західних областей України. 5 жовтня 1944 р. - 14 грудня 1944 р. 72 арк.

10. Державний архів Тернопільської області. Ф. П 1. Оп. 1. Спр. 2. Протокол І обласної партійної конференції КП(б)У. 23 квітня 1940 р. - 25 квітня 1940 р. 40 арк.

11. Державний архів Тернопільської області. Ф. П 1. Оп. 1. Спр. 3. Стенограма I обласної партійної конференції КП(б)У. 23 квітня 1940 р. - 26 квітня 1940 р. 187 арк.

12. Державний архів Тернопільської області. Ф. П-1. Оп. 1. Спр. 9. Протоколи 3-5 засідання обкому КП(б)У. 13 травня 1940 р. - 25 травня 1940 р. 128 арк.

13. Державний архів Тернопільської області. Ф. П-1. Оп. 1. Спр. 13. Протоколи 18-22 засідання обкому КП(б)У. 3 вересня 1940 р. - 3 жовтня 1940 р. 160 арк.

14. Державний архів Тернопільської області. Ф. П-1. Оп. 1. Спр. 15. Протоколи 26-33 засідання обкому КП(б)У. 23 жовтня 1940 р. - 23 листопада 1940 р. 291 арк.

15. Державний архів Тернопільської області. Ф. П-1. Оп. 1. Спр. 29. Протоколи 63-67 засідання бюро Тернопільського обкому КП(б)У. 15 травня 1941 р. - 3 червня 1941 p. 160 арк.

16. Грушецький I. Соціалістичні перетворення на Львівщині. Львів: Вільна Україна, 1950. 37 с.

17. Келембетова В. Ю. Побут і релігійні пережитки: (етнографічно-соціологічне дослідження). Київ: Наукова думка, 1974. 188 с.

18. Киричук Ю. Український національний рух 40-50-х років XX століття: ідеологія та практика. Львів: Добра справа, 2003. 464 с.

19. Ковалюк В. Р. Культурологічні та духовні аспекти «радянізації» Західної України (вересень 1939 - червень 1941 р.) // Український історичний журнал. 1993. № 2-3. С. 3-17.

20. Коковін О. Громадсько-педагогічні ініціативи українського педагогічного товариства «Рідна Школа» в Бережанському повіті (перша половина XX ст.). // Матеріали Міжнародної науково-практичної конференції «Тернопіль і Тернопілля в історії та культурі України і світу (від найдавніших часів до сьогодення). / За заг. ред. проф. I. С. Зуляка. Тернопіль : Вид-во ТНПУ ім. В. Гнатюка, 2012. Ч. 1.С. 109-112.

21. Кондратюк К. Політичні, соціально-економічні та духовні аспекти «радянізації» західних областей України у 1939-1941 роках. // 1939 рік в історичній долі України і українців : матеріали Міжнар. Наук. конф. 23-24 вересня 1999 р. Львів, 1999. С. 20-30.

22. Корнієць Л. Соціалістичні перетворення в Західних областях Української РСР. Київ: Держполітвидав, 1950. 31 с.

23. Котовський Р. Зміни у повсякденному житті галицько-волинського села у 1939-1941pp. // Наукові записки Тернопільского національного педагогічного університету імені Володимира Гнатюка. Серія: Історія / За заг. ред. проф. І. С. Зуляка. Тернопіль : Вид-во ТНПУ ім. В. Гнатюка, 2011. Вип. 1. С. 136-141. 
24. Кравчук Л. Ідеологізація та радянізація культосвітніх установ Тернопільщини (вересень 1939 - червень 1941 pp. // Наукові записки Тернопільского національного педагогічного університету імені Володимира Гнатюка. Серія: Історія / За заг. ред. проф. І.С. Зуляка. Тернопіль : Вид-во ТНПУ ім. В. Гнатюка, 2016. Вип. 1. Ч. 4. С. 63-67.

25. Кувеньов О. Ф. Громадський побут українського селянства: історико-етнографічний нарис. Київ: Наукова думка, 1966. 133 с.

26. Культурне життя в Україні. Західні землі : документи і матеріали. Київ : Наук. думка, 1995. T. $1.749 \mathrm{c.}$

27. Кучерепа М. М., Вісин В. В. Волинь: 1939-1941 рр.: навчальний посібник. Луцьк : Волинська обласна друкарня, 2005. 486 с.

28. Литвин М. Р. 1939. Західні землі України. Львів : Інститут українознавства ім. І. Крип'якевича НАН України, 1999. 151 с.

29. Львівське обласне лекційне бюро. Опорні теми лекцій на 1940/1941 рр. Львів, 1940. 48 с.

30. Митрополит Андрей Шептицький : життя і діяльність : документи і матеріали, 1899-1944. Т. 2 Церква і суспільне питання. Львів: «Місіонер», 1999. 572 с.

31. Рудницька М. Західна Україна під більшовиками: збірник. Нью-Йорк : НТШ ім. Т. Шевченка в Америці, 1958. 494 с.

32. Соціалістичні перетворення в культурі та побуті західноукраїнських областей України (1939-1989). Київ : Наукова думка, 1989. 264 с.

33. Центральний державний історичний архів у м. Львів. Ф. 201. Оп. 1. Спр. 33. Звіти, відомості про суспільно-політичне та економічне становище парафій Долинського, Жидачівського, Журавенського, Заложцівського і Збаражського деканатів для шематизму на 1944 р. 1941 р. - 1943 р. 66 арк.

34. Центральний державний історичний архів у м. Львів. Ф. 201. Оп. 1. Спр. 34. Звіти, відомості про суспільно-політичне та економічне становище парафій Зборівського, Золочівського, Калуського деканатів для шематизму на 1944 р. 1941 р. - 1943 р. 34 арк.

35. Центральний державний історичний архів у м. Львів. Ф. 201. Оп. 1. Спр. 36. Звіти, відомості про суспільно-політичне та економічне становище парафій Микулинецького, Нараївського, Новосельського, Новострілищанського, Озірнянського і Олеського деканатів для шематизму на 1944 р. 1942 р. - 1943 р. 77 арк.

36. Центральний державний історичний архів у м. Львів. Ф. 201. Оп. 1. Спр. 41. Звіти, відомості про суспільно-політичне та економічне становище парафій Унівського, Ходорівського, Щирецького, Янівського і Яричівського деканатів для шематизму на 1944 p. 1941 р. -1943 р. 70 арк.

\section{REFERENCES}

1. Baran, V. K., Tokarskyi, V. V. (2014). «Zachystka»: politychni represii v zakhidnykh oblastiakh Ukrainy u 1939-1941 rr. [Purge": political repressions in the western regions of Ukraine in 1939-1941]. Lviv : Instytut ukrainoznavstva im. I. Krypiakevycha NAN Ukrainy [in Ukrainian].

2. Stenohramma soveshchanyia sekretarei ukomov partyy, zaveduiushchykh sektoramy ahytatsyy y propahandy, pervykh sekretarei ukomov komsomola, komyssarov y nachalnykov polytotdelov voynskykh chastey o sostoianyy partyino-massovoi raboty $\mathrm{v}$ oblasty [Transcript of the meeting of secretaries of party ukoms, heads of agitation and propaganda sectors, first secretaries of komsomol ukoms, commissioners and heads of political departments of military units on the state of mass party work in the field]. DAIFO (Derzhavnyi arkhiv Ivano-Frankivskoi oblasti). F. P. 1. Op. 1. Spr. 5. 21 december 1939 - 21 december 1939. 60 [in Ukrainian].

3. Postanovy oblvykonkomu pro poriadok provedennia mistsevykh podatkiv i zboriv v $1941 \mathrm{r}$. po Stanislavskii oblasti [Hold an order to the regional order about the conduct of taxes in $1941 \mathrm{p}$. on Stanislav region.]. DAIFO (Derzhavnyi arkhiv Ivano-Frankivskoi oblasti). F. R. 1. Op. 1. Spr. 787. 28 September 1940 r. - 1 October 1940. 65 [in Ukrainian].

4. Spohady Konyshchuk M.O. 1892 r.n. s. Kovalivka Stanislavskoi oblasti [Memoirs Konischuk M.O. 1892 y. b. v. Kovalivka Stanislav region]. DAIFO (Derzhavnyi arkhiv Ivano-Frankivskoi oblasti). F. R. 1576. Op. 1. Spr. 144. 1965. 35 [in Ukrainian].

5. Nakazy vykonavchoho komitetu. Spysky, dovidky, skhemy po vyborakh u VR SRSR i URSR [Punish the victimist comittee. Lists, messages, schemas on vibors of SP CPRS and UPRS]. DALO. (Derzhavnyi arkhiv Lvivskoi oblasti). F. 221. Op. 1. Spr. 79. 1 September $1940-8$ March 1940. 370 [in Ukrainian]. 
6. Informatsiia pro stan hospodarskoho, kulturnoho i politychnoho zhyttia trudiashchykh Zolochivskoho povitu za $1939 \mathrm{r}$ stanom na $15.11 .1939 \mathrm{r}$. [Information on the state of economic, cultural and political life of the working people of Zolochiv district in 1939 as of 15.11.1939]. DALO. (Derzhavnyi arkhiv Lvivskoi oblasti). F. 221. Op. 1. Spr. 363. 1939. 3 [in Ukrainian].

7. Dopovidni, poiasniuvalni zapysky, vidomosti oblasnykh radianskykh orhaniv v obkom KP(b)U pro stan promyslovosti, silskoho hospodarstva, narodnoi osvity, torhivli, okhorony zdorovia $\mathrm{V}$ oblasti, vidomosti pro vysunennia na kerivni posady predstavnykiv z mistsevoho naselennia [Reports, explanatory notes, information of the regional Soviet bodies in the regional committee of the $\mathrm{CP}(\mathrm{b}) \mathrm{U}$ on the state of industry, agriculture, public education, trade, health care in the region, information on the nomination of representatives of the local population to the leading positions.]. DALO. (Derzhavnyi arkhiv Lvivskoi oblasti). F. P 3. Op. 1. Spr. 13. 2 January 1940 r. - 10 May 1940 r. 140 [in Ukrainian].

8. Informatsii pratsivnykiv obkomu, miskkomiv, raikomiv partii pro vykonannia postanov "Pro nedoliky v politychnii roboti sered naselennia Zakhidnykh oblastei URSR" [Information of the employees of the regional committee, city committees, party district committees on the implementation of the resolutions "On the shortcomings in political work among the population of the western regions of the Ukrainian SSR"]. DALO. (Derzhavnyi arkhiv Lvivskoi oblasti). F. P 3. Op. 1. Spr. 60. 9 May 1944 r. - 20 June 1944 r. 136 [in Ukrainian].

9. Informatsii, dovidky obkomu partii v TsK KP(b)U pro vykonannia postanov TsK VKP(b) vid 27.09.1944 r. Pro nedoliky v politychnii roboti sered naselennia zakhidnykh oblastei Ukrainy [Information, certificates to the regional committee of the party in the Central Committee of the $\mathrm{CPU}(\mathrm{b}) \mathrm{U}$ on the implementation of the resolutions of the Central Committee of the CPSU(b) dated September 27, 1944, on the shortcomings in political work among the population of the western regions of Ukraine]. DALO. (Derzhavnyi arkhiv Lvivskoi oblasti). F. P 3. Op. 1. Spr. 75. 5 October 1944 r. - 14 December 1944 r. 72 [in Ukrainian].

10. Protokol I oblasnoi partiinoi konferentsii KP(b)U [Protocol I of the regional party conference KP (b) U]. DALO. (Derzhavnyi arkhiv Ternopilskoi oblasti). F. P 1. Op. 1. Spr. 2. 23 April 1940 r. 25 April 1940 r. 40 [in Ukrainian].

11. Stenohrama I oblasnoi partiinoi konferentsii $\mathrm{KP}(\mathrm{b}) \mathrm{U}$ [transcript I of the regional party conference KP (b) U]. DALO. (Derzhavnyi arkhiv Ternopilskoi oblasti). F. P 1. Op. 1. Spr. 3. 23 April 1940 r. - 26 April 1940 r. 187 [in Ukrainian].

12. Protokoly 3-5 zasidannia obkomu KP(b)U [Protocols 3-5 of the meeting of the Regional Committee of the CP(b)U]. DALO. (Derzhavnyi arkhiv Ternopilskoi oblasti). F. P 1. Op. 1. Spr. 9. 13 May 1940 r. - 25 May 1940 r. 128 [in Ukrainian].

13. Protokoly 18-22 zasidannia obkomu KP(b)U [Protocols 18-22 of the meeting of the Regional Committee of the CP(b)U]. DALO. (Derzhavnyi arkhiv Ternopilskoi oblasti). F. P 1. Op. 1. Spr. 13. 3 September 1940 r. -3 October 1940 r. 160 [in Ukrainian].

14. Protokoly 26-33 zasidannia obkomu KP(b)U [Protocols 26-33 of the meeting of the Regional Committee of the CP(b)U]. DALO. (Derzhavnyi arkhiv Ternopilskoi oblasti). F. P 1. Op. 1. Spr. [in Ukrainian].

15. Protokoly 63-67 zasidannia biuro Ternopilskoho obkomu KP(b)U [Protocols $63-67$ of the meeting of the Regional Committee of the CP(b)U]. DALO. (Derzhavnyi arkhiv Ternopilskoi oblasti). F. P 1. Op. 1. Spr. 29. 15 May 1941 r. - 3 June 1941 r. 160 [in Ukrainian].

16. Hrushetskyi, I. (1950). Sotsialistychni peretvorennia na Lvivshchyni [Socialist transformation in Lviv region]. Lviv: Vilna Ukraina [in Ukrainian].

17. Kelembetova, V. Iu. (1974). Pobut i relihiini perezhytky: (etnohrafichno-sotsiolohichne doslidzhennia) [Life and religious remnants: (ethnographic and sociological study]. Kyiv: Naukova dumka [in Ukrainian].

18. Kyrychuk, Yu. (2003). Ukrainskyi natsionalnyi rukh 40-50-kh rokiv KhKh stolittia: ideolohiia ta praktyka [Ukrainian national movement of the 40's and 50's of the twentieth century: ideology and practice]. Lviv: Dobra sprava [in Ukrainian].

19. Kovaliuk, V. R. (1993). Kulturolohichni ta dukhovni aspekty «radianizatsii» Zakhidnoi Ukrainy (veresen 1939 - cherven 1941 r.) [Cultural and spiritual aspects of «Sovietization» of Western Ukraine (September 1939 - June 1941)]. Ukrainskyi istorychnyi zhurnal - Ukrainian Historical Magazine. 2-3. 3-17 [in Ukrainian].

20. Kokovin, O. (2012). Hromadsko-pedahohichni initsiatyvy ukrainskoho pedahohichnoho tovarystva «Ridna Shkola» V Berezhanskomu poviti (persha polovyna XX st.) [Public- 
pedagogical initiatives of the Ukrainian Pedagogical Society «Native School» in Berezhany district (first half of the twentieth century)]. Materialy Mizhnarodnoi naukovo-praktychnoi konferentsii «Ternopil $i$ Ternopillia $v$ istorii ta kulturi Ukrainy $i$ svitu (vid naidavnishykh chasiv do sohodennia) - Materials of the International Scientific and Practical Conference "Ternopil and Ternopil in the history and culture of Ukraine and the world (from ancient times to the present). 1. 109-112 [in Ukrainian].

21. Kondratiuk, K. (1999). Politychni, sotsialno-ekonomichni ta dukhovni aspekty «radianizatsii» zakhidnykh oblastei Ukrainy u 1939-1941 rokakh [Political, socio-economic and spiritual aspects of «Sovietization» of the western regions of Ukraine in 1939-1941.]. 1939 rik v istorychnii doli Ukrainy i ukraintsiv: materialy Mizhnar. Nauk. konf. 23-24 veresnia $1999 r .-1939$ in the historical destiny of Ukraine and Ukrainians: materials of the International Science conf. September 23-24, 1999, 20-30 [in Ukrainian].

22. Korniiets, L. (1950). Sotsialistychni peretvorennia v Zakhidnykh oblastiakh Ukrainskoi RSR [Socialist transformations in the western regions of the Ukrainian SSR.]. Kyiv: Derzhpolitvydav, 31 [in Ukrainian].

23. Kotovskyi, R. (2011). Zminy u povsiakdennomu zhytti halytsko-volynskoho sela u 1939-1941 rr. [Changes in the everyday life of Galitsko-Volyn village in 1939-1941]. Naukovi zapysky Ternopilskoho natsionalnoho pedahohichnoho universytetu imeni Volodymyra Hnatiuka. Seriia: Istoriia - Scientific notes of Ternopil National Pedagogical University named after Volodymyr Hnatyuk. Series: History. 1. 136-141 [in Ukrainian].

24. Kravchuk, L. (2016). Ideolohizatsiia ta radianizatsiia kultosvitnikh ustanov Ternopilshchyny (veresen 1939 - cherven 1941 rr.) [Ideologicalization and Sovietization of Cultural Institutions of Ternopil Oblast (September 1939 - June 1941)]. Naukovi zapysky Ternopilskoho natsionalnoho pedahohichnoho universytetu imeni Volodymyra Hnatiuka. Seriia: Istoriia - Scientific notes of Ternopil National Pedagogical University named after Volodymyr Hnatyuk. Series: History, 1 part 4, 63-67 [in Ukrainian].

25. Kuvenov, O. F. (1966). Hromadskyi pobut ukrainskoho selianstva: istoryko-etnohrafichnyi narys [The public life of the Ukrainian peasantry: historical and ethnographic essay]. Kyiv: Naukova dumka, 133 [in Ukrainian].

26. (1995). Kulturne zhyttia v Ukraini. Zakhidni zemli : dok. i materialy [Cultural life in Ukraine. Western lands: documents and materials.] Kyiv : Nauk. dumka, T. 1, 749 [in Ukrainian].

27. Kucherepa, M. M., Visyn, V. V. (2005). Volyn: 1939-1941 rr.: navchalnyi posibnyk [Volyn: 19391941: educational aid.]. Lutsk : Volynska oblasna drukarnia [in Ukrainian].

28. Lytvyn, M. R. (1999). 1939. Zakhidni zemli Ukrainy [1939. Western lands of Ukraine.]. Lviv : Instytut ukrainoznavstva im. I. Krypiakevycha NAN Ukrainy [in Ukrainian].

29. (1940). Lvivske oblasne lektsiine biuro. Oporni temy lektsii na 1940/1941 rr. [Lviv regional lecture bureau. The support topics of lectures for 1940/1941]. Lviv [in Ukrainian].

30. (1999). Mytropolyt Andrei Sheptytskyi : zhyttia i diialnist : dokumenty i materialy, 1899-1944. T. 2. Tserkva i suspilne pytannia [Metropolitan Andrey Sheptytsky: Life and Activities: Documents and Materials, 1899-1944. T. 2. The Church and the public question]. Lviv, «Misioner» [in Ukrainian].

31. Rudnytska, M. (1958). Zakhidnia Ukraina pid bolshevykamy: zbirnyk [Western Ukraine under the Bolsheviks: collection]. Niu-York: NTSh im. T. Shevchenka v Amerytsi [in Ukrainian].

32. (1989). Sotsialistychni peretvorennia v kulturi ta pobuti zakhidnoukrainskykh oblastei Ukrainy (1939-1989) [Socialist transformations in the culture and everyday life of the West Ukrainian regions of Ukraine (1939-1989)]. Kyiv : Naukova dumka [in Ukrainian].

33. Zvity, vidomosti pro suspilno-politychne ta ekonomichne stanovyshche parafii Dolynskoho, Zhydachivskoho, Zhuravenskoho, Zalozhtsivskoho i Zbarazhskoho dekanativ dlia shematyzmu na 1944 r. [Reports, information on the socio-political and economic situation of the parishes of the Dolinsky, Zhydachivsky, Zhuravsky, Zalozhtsivsky and Zbarazh deanships for the report of 1944]. TDIAL. (Tsentralnyi derzhavnyi istorychnyi arkhiv u m. Lviv). F. 201. Op. 1. Spr. 33. 1941 r. - 1943 r. 66 [in Ukrainian].

34. Zvity, vidomosti pro suspilno-politychne ta ekonomichne stanovyshche parafii Zborivskoho, Zolochivskoho, Kaluskoho dekanativ dlia shematyzmu na 1944 r. [Reports, information on the socio-political and economic situation of the parishes of Zborivsky, Zolochivsky and Kalush deanships for the report in 1944]. TDIAL. (Tsentralnyi derzhavnyi istorychnyi arkhiv u m. Lviv). F. 201. Op. 1. Spr. 34. 1941 r. - 1943 r. 34 [in Ukrainian]. 
35. Zvity, vidomosti pro suspilno-politychne ta ekonomichne stanovyshche parafii Mykulynetskoho, Naraivskoho, Novoselskoho, Novostrilyshchanskoho, Ozirnianskoho i Oleskoho dekanativ dlia shematyzmu na 1944 r. [Reports, information on the socio-political and economic situation of parishes of the Mykulynetsky, Narayevsky, Novoselsky, Novostrilyshchansky, Ozirnia and Oles'ka deanships for the report of 1944]. TDIAL. (Tsentralnyi derzhavnyi istorychnyi arkhiv u m. Lviv). F. 201. Op. 1. Spr. 36.1942 r. - 1943 r. 77 [in Ukrainian].

36. TDIAL. (Tsentralnyi derzhavnyi istorychnyi arkhiv u m. Lviv). F. 201. Op. 1. Spr. 41. Zvity, vidomosti pro suspilno-politychne ta ekonomichne stanovyshche parafii Univskoho, Khodorivskoho, Shchyretskoho, Yanivskoho i Yarychivskoho dekanativ dlia shematyzmu na 1944 r. [Reports, information on the socio-political and economic situation of the parishes of the Univsky, Khodorovsky, Shchyretsky, Yanivsky and Yarichiv deanships for the report of 1944]. 1941 r. - 1943 r. 70 [in Ukrainian]. 